\title{
Risk of recurrence and new malignant cutaneous neoplasms in Mexican subjects with basal cell carcinoma
}

\section{Riesgo de recurrencia y de nuevas neoplasias cutáneas malignas en sujetos mexicanos con carcinoma basocelular}

José F. Ruiz-González', Elizabeth Guevara-Gutiérrez', Mercedes Hernández-Torres, Guillermo Solís-Ledesma ${ }^{1}$ and Alberto Tlacuilo-Parra ${ }^{2 *}$

${ }^{1}$ Instituto Dermatológico de Jalisco Dr. José Barba Rubio, Secretaría de Salud de Jalisco, Zapopan; ${ }^{2} H i g h$ Specialty Medical Unit Pediatrics Hospital, Centro Médico Nacional de Occidente del Instituto Mexicano del Seguro Social, Guadalajara, Jalisco, Mexico

\begin{abstract}
Introduction: Basal cell carcinoma $(B C C)$ is the most common skin malignant neoplasm. Objective: Investigate the risk of recurrence and of new skin malignant neoplasms, after treatment of BCC. Method: Retrospective study. We examined the files of patients with histopathological diagnosis of primary BCC, between January 2007 and December 2009, and we investigate number of recurrences and their relationship with localization, treatment type, and histopathological variant, and the number of new skin malignant neoplasms. For analysis, we employed descriptive and inferential statistics; $p<0.05$ was considèred significant. Results: $A$ total of 397 patients, with an average follow-up of $4 \pm 1.5$ years. Recurrences presented in $4 \%$. Recurrences were related with longer time of evolution (36 vs. 32 months; $p=0.04$ ) and treatment with destructive techniques (electrofulguration, cryosurgery or imiquimod; 31 vs. $4 \% ; p<0.001$ ). There was no relationship with localization, or the histopathological variant. The risk of developing a new malignant neoplasm was $25 \% ; 66 \%$ corresponded to a new BCC and $30 \%$ to squamous cell carcinoma. Conclusions: Follow-up of patients with BCC should be conducted independently of their tocalization and histopathological variant, especially in patients with greater evolution time, principally with surgical techniques.
\end{abstract}

KEY WORDS: Basal cell carcinoma. Recurrence. Skin cancer.

\section{Resumen}

Introducción: El carcinoma basocelular $(C B C)$ es la neoplasia cutánea maligna más común. Objetivo: se investigó el riesgoo de recurrencia y de nueva neoplasia cutánea maligna después del tratamiento de CBC. Método: Estudio retrospectivo. Fueron identificados los pacientes con diagnóstico histopatológico de CBC primario, de enero de 2007 a diciembre de 2009, y se revisarron los expedientes para investigar el número de recurrencias, la localización, el tipo de tratamiento y la variante histopatologica, determinando nuevas neoplasias cutáneas malignas. El análisis incluyó estadística descriptiva e inferencial, considerando signnificativa una $p<0.05$. Resultados: Se incluyeron 397 pacientes, con un seguimiento promedio de $4 \pm 1.5$ años. La recurrencia se presentó en el $4 \%$ y se relacionó con un mayor tiempo de evolución (36 vs. 32 meses; $p=0.04$ ) y haber sido tratado mediante técnicas destructivas (electrofulguración, criocirugía o imiquimod; $31 \mathrm{vs.} \mathrm{4 \% ;} p=0.0004$ ). No hubo relación con la localizaciôn ni con la variante histopatológica. El riesgo de desarrollar una nueva neoplasia maligna fue del 25\%, y de ellas el 66\% correspondió a un nuevo CBC y el 30\% a carcinoma espinocelular. Conclusiones: Es importante el seguimiento de los pacientes con EBC para identificar tanto las recurrencias como las nuevas neoplasias malignas, independientemente de la localización y de la varijante histopatológica del primario. El tratamiento con técnicas quirúrgicas condiciona una menor recaída que las técnicas destructivas.

PALABRAS CLAVE: Carcinoma basocelular. Recurrencia. Cáncer cutáneo.

\section{Correspondence:}

*Alberto Tlacuilo-Parra

Monte Olimpo 1413,

Col. Independencia, C.P.44340, Guadalajara Jal. México

E-mail: albtlacuilo.@yahoo.com
Date of reception: 26-02-2018

Date of acceptance: 09-05-2018

DOI: $10.24875 / C I R U E . M 18000063$
Cir Cir. 2018;86:366-371

Contents available at PubMed www.cirugiaycirujanos.com 


\section{Introduction}

Basal cell carcinoma (BCC) is the most commonly diagnosed malignant neoplasm in dermatological practice; it accounts for $65-74 \%$ of all skin tumors ${ }^{1-4}$ and its incidence has increased over the years in different countries ${ }^{5-7}$. In Mexico, a prevalence of 3.9 per 1000 population is estimated ${ }^{2,8}$. Although it has a low risk for producing metastasis, the risk of recurrence varies from 2 to $10 \% \%^{9-12}$, and the risk for developing a new malignancy ranges from $10.4 \%$ to $21.2 \%^{13,14}$. This depends on tumor clinical-histopathological characteristics, with location on the nose, eyelids, the temple, the helix or the neck, size larger than $10 \mathrm{~mm}$, morpheaform histopathological pattern or recurrent $\mathrm{BCC}^{15}$ being factors of higher risk, as well as the type of treatment used, with recurrence rates being higher when destructive techniques such as electrofulguration ${ }^{16}$, cryosurgery $(10 \%)^{12}$ or imiquimod $(20.6 \%)$ are employed ${ }^{17}$, while with excision with predetermined margins recurrence is lower $(2 \%)^{10,11}$. We did not find studies carried out in Mexico on the subject, and our goal was therefore to investigate, in patients diagnosed with BCC, which factors were associated with $B C C$ recurrence and if said recurrence is related to patient clinical characteristics or of the tumor itself, as well as to determine the frequency of new malignant skin neoplasms.

\section{Method}

Retrospective study, where patients with primary BCC histopathological diagnosis recorded at Jalisco Dermatological Institute database from January 1, 2007 to December 31, of 2009, who had at least 2 years' follow-up after BCC treatment, were included. Electronic records were reviewed to investigate age, gender and evolution time, as well as to determine the number of recurrences (evidence of malignant tumor cells consistent with $\mathrm{BCC}$ on the previously-treated primary BCC scar or at $2 \mathrm{~cm}$ from it, and at least 2 months after treatment) ${ }^{9}$, and new malignant skin neoplasms (histopathologically confirmed; if it was a new BCC, it should be at least $2 \mathrm{~cm}$ apart from the previously-treated BCC scar or could be on the scar if the diagnosis was other than $\mathrm{BCC})^{14}$. The relationship of the percentage of recurrences with the location, type of treatment and BCC histopathological variant was investigated. Records of patients whose histopathological diagnosis was obtained from a biopsy and not from the result of tumor complete excision were excluded. For data analysis, averages and standard deviations were calculated. For the compariso of qualitative variables, the chi-square test or Fisher's exact test were used, as appropriate. For quantitative variables, Student's t-test was used. To estimate the relationship between the risk of recurrent BCC and clinical and histopathological characteristics, the odds ratio with a $95 \%$ confidence interval was calculated. Statistical significance was considered with a $p$-vâlue $<0.05$. For the processing of data, the Microsoft EX 2013 and Epi Info ${ }^{\mathrm{TM}}$ (version 7.0) programs were used. This investigation was approved by the Ethics and Research Committee of the institution.

\section{Results}

\section{General characteristics}

During the study period, 397 patients with primary $\mathrm{BCC}$ diagnosis met the selection criteria. Average age was $65 \pm 13$ years (range: 16 to 98 years), and 956 subjects $(39 \%)$ were males and $241(61 \%)$ females. Average BCC evolution time at diagnosis was $33.5 \pm$ 44 months (range: 1 month to 20 years). Average follow-up time was $4 \pm 1.5$ years (range: 2 to 10 years). The received treatment was grouped in two modalities: surgical (surgery with predetermined margins or Mohs micrographic surgery), which was used in 378 patients (95\%), and destructive (electrofulgurration, cryosurgery and imiquimod), which was employed in 19 patients (5\%).

\section{Recurrent BCC}

Recurrent BCC was found in 16 patients (4\%), with a median reappearance time of 24 months (range: 2 months to 4.8 years). Female gender predominated, with 10 cases $(62.5 \%)$. Median age was 71 yeers (range: 47 to 98 years) and median primary BCC evolution time was 36 months (range: 4 months to 15 years).

Anatomical localization was as follows: $\mathrm{H}$ or high-risk zone (eyelids, eyebrows, periorbital region, nose; lips cutaneous and vermilion portions, chin, mandibular region, preauricular and retroauricular areas) in 8 cases $(50 \%)$, and $L$ or medium risk zone (scalp, forehead, cheeks and neck) in 8 cases $(50 \%)$. No recurrences were observed in the $\mathrm{M}$ or low-risk zone (trunk and extremities). In 11 patients (69\%) surgical techniques were used, whereas in $5(31 \%)$, destructive techniques 


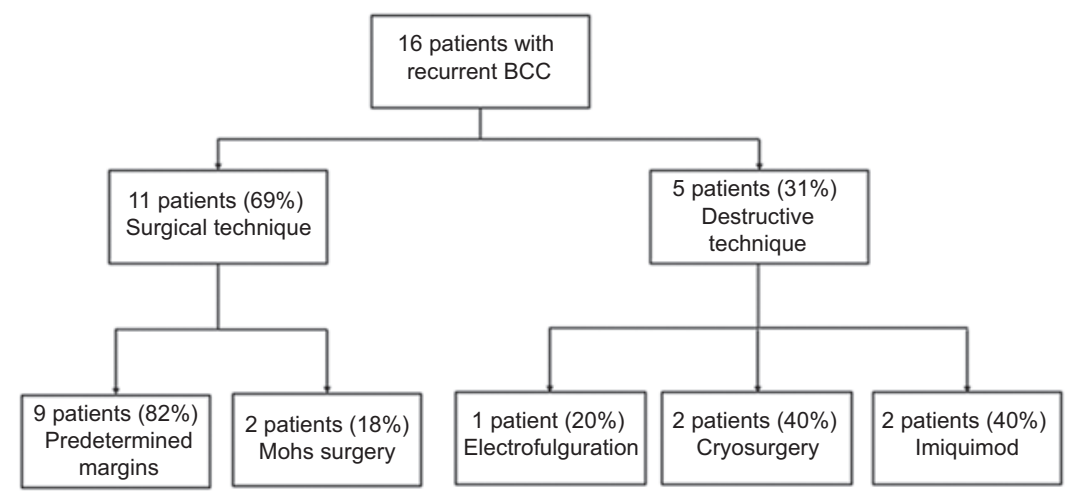

Figure 1. Recurrent basal cell carcinoma (BCC) treatment.

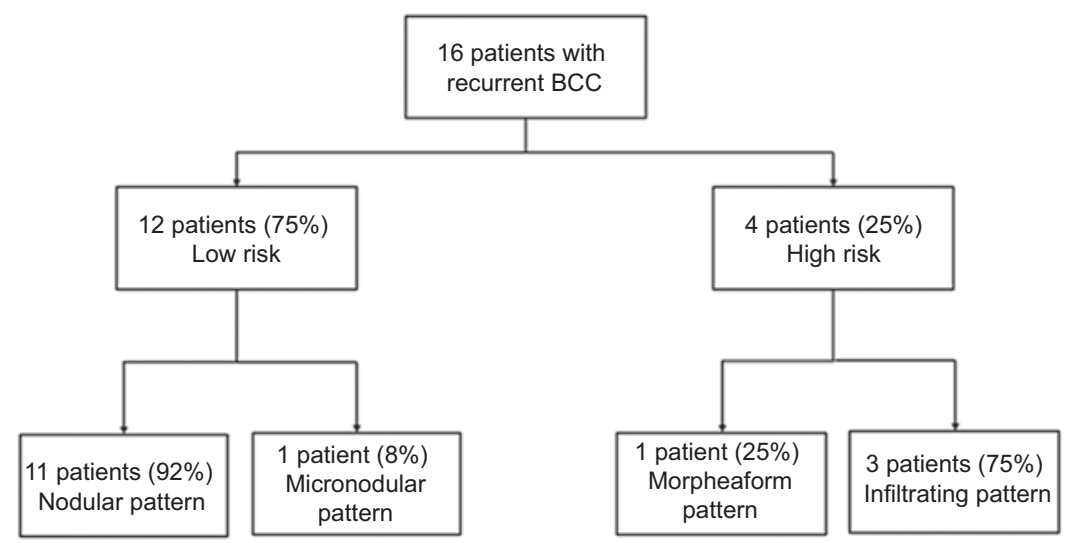

Figure 2. Recurrent basal cell carcinoma (BCC) histopathological variants.

were used (Fig. 1). The low-risk histopathological pattern was present in 12 patients $(75 \%)$, and the highrisk pattern in 4 (25\%) (Fig. 2).

When the group of 16 patients with recurrent BCC and the group of 381 patients who had no recurrent $\mathrm{BCC}$ were compared, we found statistically significant differences in evolution time (36 vs. 32 months; $p=0.04$ ), use of surgical techniques (69 vs. $96 \%$; $p=0.0004)$ and the use of destructive techniques (31 vs. $4 \% ; p=0.0004$ ). Table 1 shows the comparison between the variables of the cases with and without recurrent $\mathrm{BCC}$.

\section{New malignant skin neoplasms}

Of the 397 patients diagnosed with primary BCC, 98 had a total of 147 new skin malignancies (25\%): one new tumor in 70 patients $(72 \%)$, two new tumors in $17(17 \%)$ and three or more tumors in $11(11 \%)$. Average onset time was $32 \pm 45$ months (range: 2 months to 15 years). Among these, BCC occurred in 97 cases $(66 \%)$, while squamous cell carcinoma developed in $44(30 \%)$. Low risk BCC predominated, with 66 cases $(68 \%)$, and out of them, the most cômmon histopathological pattern was nodular in 48 (7\%\%). Histopathological characteristics of the 147 new-malignant skin neoplasms are shown in figure 3.

When the characteristics of the group of patients who developed a new malignant skin neoplasm were compared with those of the group of patients whoodid not, no statistically significant differences were foutnd (Table 2).

\section{Discussion}

This study included 397 patients with primary BCC, a sample larger than that of Marghoob et al. 260 patients ${ }^{4}$ and to that of McLoone et al..$^{13}$ of $114 \mathrm{pa}$ tients. Average age was 65 years, similar to the age of 62 reported in other Mexican studies ${ }^{2,8}$. The female gender predominated, with $61 \%$ of cases, which differs from findings of others authors, who report a predominance of the male gender ${ }^{2,8,18}$. BCC evolution time at diagnosis was, on average, 33.5 months, 


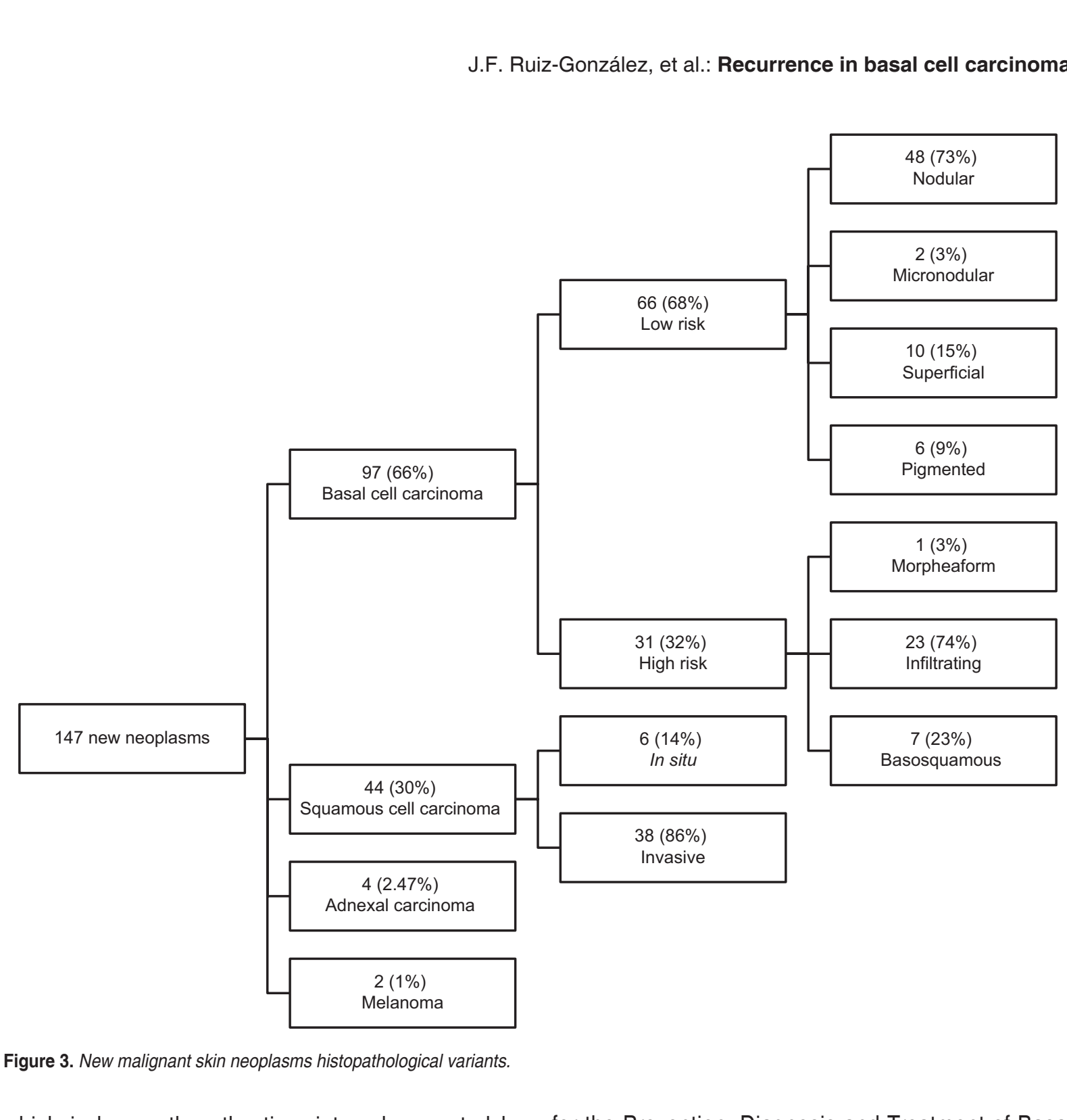

which is longer than the time intervals reported by other authors who refer that, in most cases, the diagnosis is made prior to 12 months of evolution ${ }^{19}$. Followup time after diagnosis was, on average, 4 years, which is less than that reported by Chren et al. ${ }^{9}$, which was 7.4 years on average, but longer than that referred by McLoone et al. ${ }^{13}$, who carried out a follow-up of 2 years, part of it through telephone calls and not through physical examination.

The risk of recurrent BCC was $4 \%$, similar to the prevalence of $3.3 \%$ reported for a USA population in the aforementioned study by Chren, et al. ${ }^{9}$. In our study, recurrence occurred on average 25 months after the primary BCC diagnosis, but there were recurrences at up to 4.8 years, which is longer than the recurrence-free interval reported by Chren et al. ${ }^{9}$, which was 3.9 years. This finding is important, since in Mexico, according to the Clinical Practice Guidelines

for the Prevention, Diagnosis and Treatment of Basal Cell Carcinoma ${ }^{20}$, the recommendation is a 3 -year follow-up in high-risk patients; therefore, perhaps a longer follow-up would be desirable. We found asignificantly longer evolution time in those patients with recurrence, which suggests that we should be especially careful with patients with long-evolving lesions.

Of the primary BCCs that recurred, $50 \%$ were found to be in high-risk areas, while other authors reporthis location in $81 \%$ of cases $^{21}$. We did not find recurrences in tumors located at low-risk areas, which parfially supports the recommendation of the British Association of Dermatologists of following only patients-with tumors on high-risk anatomical sites or with agğressive histological type 22 .

The risk of recurrence was significantly higher with the use of destructive techniques than when surgical 
Table 1. Comparison between recurrent and non-recurrent basal cell carcinomas

\begin{tabular}{|c|c|c|c|c|c|}
\hline Variable & Recurrent BCC $(n=16)$ & Non-recurrent BCC $(n=381)$ & p & OR $\left(95^{\circ}\right.$ & $\%$ Cl) \\
\hline Age in years $( \pm S D)$ & $71^{*}$ & $65 \pm 12$ & $0.54^{\dagger}$ & - & $\gtrsim$ \\
\hline Female gender, n (\%) & $10(62.5)$ & $231(61)$ & $0.88^{\ddagger}$ & $1.08(0.35$ & $5-3.43)$ \\
\hline Evolution, months ( $\pm \mathrm{SD}$ ) & $36^{*}$ & $32 \pm 43$ & $0.04^{\dagger}$ & - & $\frac{1}{2}$ \\
\hline High-risk zone, n (\%) & $8(50)$ & $222(58)$ & $0.43^{\ddagger}$ & $0.72(0.2$ & $4-2.15)$ \\
\hline Medium-risk zone, n (\%) & $8(50)$ & $123(32)$ & $0.13^{\ddagger}$ & $2.10(0.7 C$ & $-6.31)$ \\
\hline Low-risk zone, n (\%) & $0(0)$ & $36(9)$ & $0.38^{\S}$ & - & 을 \\
\hline Surgical technique, n (\%) & $11(69)$ & $367(96)$ & $0.0004 \S$ & - & 음 \\
\hline Predetermined margins, $n(\%)$ & $9(82)$ & $355(97)$ & $0.05^{\S}$ & - & 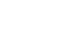 \\
\hline Mohs surgery, n (\%) & $2(18)$ & $12(3)$ & $0.05^{\S}$ & - & c \\
\hline Destructive technique, n (\%) & $5(31)$ & $14(4)$ & $0.0004^{\S}$ & - & $\cdot \frac{0}{n}$ \\
\hline High-risk histopathological pattern, n (\%) & $4(25)$ & $80(21)$ & $75^{\S}$ & - & "E \\
\hline Low-risk histopathological pattern, n (\%) & $12(75)$ & $301(79)$ & $0.75^{\S}$ & - & 르 \\
\hline \multicolumn{4}{|c|}{$\begin{array}{l}{ }^{*} \text { Median. } \\
{ }^{\dagger} \text { Mann-Whitney U-test. } \\
{ }^{*} \text { Chi-square test. } \\
\text { sTwo-tailed Fisher's exact test. } \\
\text { BCC: basal cell carcinoma; Cl: confidence interval; OR: odds ratio; SD: standard deviation. }\end{array}$} & & 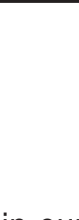 \\
\hline
\end{tabular}

Table 2. Comparison between groups with and without new malignant skin neoplasms

\begin{tabular}{|c|c|c|c|}
\hline Variable & $\begin{array}{l}\text { BCC with new } \\
\text { neoplasm } \\
(\mathrm{n}=98)\end{array}$ & $\begin{array}{c}\text { BCC without } \\
\text { new neoplasm } \\
(n=299)\end{array}$ & p \\
\hline Female gender, $\mathrm{n}(\%)$ & $53(54)$ & $188(63)$ & $0.12^{*}$ \\
\hline Age, years $( \pm S D)$ & $70 \pm 11$ & $64 \pm 13$ & $2.9^{+}$ \\
\hline Evolution, months ( \pm SD) & $32 \pm 41$ & $34 \pm 45$ & $0.79^{\dagger}$ \\
\hline Follow-up, months ( \pm SD) & $50 \pm 19$ & $49 \pm 17$ & $0.47^{\dagger}$ \\
\hline
\end{tabular}

techniques were employed, which corroborates the fact that the former have a higher rate of treatment failure ${ }^{23}$. The risk of recurrence in those patients treated with predetermined margins in our population was $2.5 \%$, which is lower than that published by Mosterd et al. ${ }^{21}$ in Dutch patients: $4.1 \%$.

As for the histopathological variant of the BCCs that recurred, the literature refers that the high-risk variant is a factor for the presence of recurrences ${ }^{15}$, but we found no significant difference with low-risk variants. Our result is similar to that published by Chren et al. ${ }^{9}$, who report that BCCs with low-risk histopathological variants also recurred more often than those with high-risk variants (3.8 vs. $1.6 \%)$.
With regard to the risk of new malignancies, incour study it was $25 \%$, which is higher than the risk reported by McLoone et al. ${ }^{13}$ in Irish population, which was $17.5 \%$. Average time at which new neoplasms appeared was 32 months, which is similar to the previously published time of 38.3 months ${ }^{14}$. There were also patients who presented with new neoplasms up to 15 years after the primary BCC diagnosis, and gerhaps a longer follow-up time should be considered, and not only 3 years, as previously mentioned $20 . \frac{c}{2}$

As for the number of new neoplasms per patient, only $11 \%$ had three or more. Conversely, Marghoob et al. $^{14}$, in 260 US patients, reported that $21.2 \%$ had three or more tumors. This higher frequency map be due to the fact that they only included fair skinhed patients, which have a higher predisposition for the development of cancer ${ }^{24}$.

The most common new malignant skin neopläsm was BCC in $66 \%$ of cases, followed by squamouscell carcinoma in $30 \%$. Both tumors are also referred by McLoone et al. ${ }^{13}$, although with lower frequencies of $16.7 \%$ and $2.6 \%$, respectively. It is important to mention that in this last study, although the follow-up time was 2 years, $47 \%$ of subjects were only contacte $\bar{d}$ by telephone and were not assessed by any doctor, which might explain these differences.

In new BCCs, the low-risk histopathological pattern prevailed, with $68 \%$ of cases, which is data that is not 
specified in previously published series. When epidemiological characteristics of patients with a new malignant skin neoplasm, such as gender, age and evolution time or follow-up, were analyzed, we found no significant differences when comparing them with those of subjects who did not develop new skin malignancies.

\section{Conflicts of interests}

\section{None to declare.}

\section{References}

1. Lucas R, McMichael T, Smith W, Armstrong B. A systematic review of worldwide incidence of nonmelanoma skin cancer. $\mathrm{Br} \mathrm{J}$ Dermatol. 2012;166:1069-80.

2. Hernández-Zárate SI, Medina-Bojórquez A, López-Tello SAL, Alcalá-Pérez $\mathrm{D}$. Epidemiología del cáncer de piel en pacientes de la Clínica de Dermato-oncología del Centro Dermatológico Dr. Ladislao de la Pascua. Estudio retrospectivo de los últimos ocho años. Dermatol Rev Mex. 2012;56:30-7.

3. Gutiérrez VRM. Cáncer de piel. Rev Fac Med UNAM. 2003;46:166-71.

4. Alfaro A, Castrejón L, Rodríguez OM. Cáncer de piel. Estudio epidemiológico a 10 años en derechohabientes del ISSSTE en Nuevo León. Dermatol Rev Mex. 2010;54:321-5.

5. Holme S. Changing trends in non-melanoma skin cancer in South Wales, 1988-1998. Br J Dermatol. 2000;143:1224-9.

6. Demers AA, Nugent Z, Mihalcioiu C, Wiseman MC, Kliewer EV. Trends of nonmelanoma skin cancer from 1960 through 2000 in a Canadian population. J Am Acad Dermatol. 2005;53:320-8.

7. Green A, Battistutta D, Hart V, Leslie D, Weedon D. Skin cancer in a subtropical Australian population: incidence and lack of association with occupation. Am J Epidemiol. 1996;144:1034-40.

8. Saucedo RAP, Gutiérrez VRM, Medina BA. Cáncer de piel en el Centro Dermatológico Pascua. Estudio epidemiológico de 10 años. Dermato Rev Mex. 2005;49:231-40.

9. Chren MM, Linos E, Torres JS, Stuart SE, Parvataneni R, Boscardin WJ. Tumor recurrence 5 years after treatment of cutaneous basal cell carcinoma and squamous cell carcinoma. J Invest Dermatol. 2013;133:1188-96.
10. Walker $P$, Hill D. Surgical treatment of basal cell carcinomas using standard postoperative histological assessment. Australas J Dermatol. 2006;47:1-12.

11. Griffiths RW, Suvarna SK, Stone J. Do basal cell carcinomas recuñafter complete conventional surgical excision? Br J Plast Surg. 2005; 58:795-805.

12. Kuflik EG. Evidence-based review of the use of cryosurgery in treatment of basal cell carcinoma. Dermatol Surg. 2003;29:566-71.

13. McLoone NM, Tolland J, Walsh M, Dolan OM. Follow-up of basal cell carcinomas: an audit of current practice. J Eur Acad Dermatol Venereol. 2006;20:698-701.

14. Marghoob A, Kopf AW, Bart RS, Sanfilippo L, Silverman MK, Lee P, et al. Risk of another basal cell carcinoma developing after treatment of a basal cell carcinoma. J Am Acad Dermatol. 1993;28:22-8.

15. Batra RS, Kelley LC. A risk scale for predicting extensive subclinical spread of nonmelanoma skin cancer. Dermatol Surg. 2002;28:107-12.

16. Rodríguez-Vigil T, Vázquez-López F, Pérez-Oliva N. Recurrence rates of primary basal cell carcinoma in facial risk areas treated with curettage and electrodesiccation. J Am Acad Dermatol. 2007;56:91-5.

17. Schulze HJ, Cribier B, Requena L, Reifenberger J, Ferrándiz C, García Díez A, et al. Imiquimod 5\% cream for the treatment of superficial basal cell carcinoma: results from a randomized vehicle-controlled phase III study in Europe. Br J Dermatol. 2005;152:939-47.

18. Roewert-Huber J, Lange-Asschenfeldt B, Stockfleth E, Kerl H. Epidemiology and aetiology of basal cell carcinoma. $\mathrm{Br} J$ Dermatol. 2007;157:S47-S51.

19. Kricker A, Armstrong B, Hansen V, Watson A, Singh-Khaira G, Lecathelinais $C$, et al. Basal cell carcinoma and squamous cell carcinomagrowth rates and determinants of size in community patients. J Am Acad Dermatol. 2014;70:456-64.

20. Guía de Práctica Clínica de Prevención, Diagnóstico y Tratamieñto del Carcinoma Basocelular. México: Secretaría de Salud; 2013.

21. Mosterd K, Krekels GA, Nieman FH, Ostertag JU, Essers BA, Dirksen $C D$, et al. Surgical excision versus Mohs' micrographic surgery for primary and recurrent basal-cell carcinoma of the face: a prospective randomised controlled trial with 5-years' follow-up. Lancet Öncol. 2008;9:1149-56.

22. Telfer NR, Colver GB, Morton CA, British Association of Dermatologists. Guidelines for the management of basal cell carcinoma. Br J Dermatol. 2008;159:35-48

23. Ceilley RI, Del Rosso JQ. Current modalities and new advances in the treatment of basal cell carcinoma. Int J Dermatol. 2006;45:489-498.

24. Chinem VP, Miot HA. Prevalence of actinic skin lesions in patients with basal cell carcinoma of the head: a case-control study. Rev Assoc Med Bras. 2011;58:188-96. 